\title{
Measurement of the respiratory electron transport system (ETS) activity in marine sediments: state-of-the-art and interpretation. I. Methodology and review of literature data
}

\author{
J. C. Relexans* \\ Laboratoire d'Océanographie Biologique, CNRS-URA 197, Université Bordeaux 1, Avenue des Facultés, \\ F-33405 Talence CEDEX, France
}

\begin{abstract}
Respiration, the biochemical transfer of electrons along respiratory chains, provides energy for maintenance and growth. Measurements of the activity of the respiratory electron transport system (ETS) have been adapted for marine studies since the 1970s. In this paper, the application of ETS activity measurements to marine sediment samples is discussed and a review of literature data is presented. From a technical point of view, extraction efficiency of the respiratory units during homogenization is the main difficulty in applying the method to sediment. It has been recognized that timeand temperature-controlled ultrasonic disruption is the most efficient extractionmethod. The dilution of the homogenate is also of critical importance for efficient recovery of ETS activity. A new, accurate method using microtitration techniques is given for laboratory and shipboard applications. Published data show that ETS activity in marine surface sediments, expressed at $20^{\circ} \mathrm{C}$, decreases strongly from coastal zones (mean: $186 \mu \mathrm{O}_{2} \mathrm{~h}^{-1} \mathrm{~g}^{-1}$ ) to the shelf $\left(38 \mu \mathrm{O}_{2} \mathrm{~h}^{-1} \mathrm{~g}^{-1}\right.$ ) and to deep sea areas (less than $5 \mu$ l $\mathrm{O}_{2} \mathrm{~h}^{-1} \mathrm{~g}^{-1}$ ), with an inflexion in the gradient at the upper continental slope. However, at least in some cases, a slight increase can be noted down the slope, where continental margins are thought to receive important carbon fluxes. Within sediment, ETS decreases generally from the surface to deeper layers. For sediments from oligotrophic areas, the gradient is regular and ETS becomes undetectable deeper than 10 to $15 \mathrm{~cm}$. However, in coastal zones, high subsurface activity levels are often found just below the oxic zone, and ETS activity is still present in deep (more than $30 \mathrm{~cm}$ ), anoxic layers.
\end{abstract}

KEY WORDS: ETS activity in sediments

\section{INTRODUCTION}

Most of the organic matter produced in, or supplied to, aquatic ecosystems is finally mineralized either in the water column or at the sediment-water interface where early diagenesis occurs. Only a small part of the organic carbon escapes the recycling processes, becoming buried for longer periods. In shallow-water systems, most mineralization takes place in the sediment (through benthic metabolism) rather than in the water column (Vosjan \& Olanczuk-Neyman 1977). However, as depth increases, the metabolic activity of

·E-mail: relexans@biocean.u-bordeaux.fr the benthos as well as its contribution to the total (water column + sediment) mineralization strongly decreases (Smith 1978, Christensen 1983). Various factors (e.g. temperature, hydrostatic pressure, nature of the dominant electron acceptors, quality and quantity of organic supply) change dramatically with increasing depth and thus strongly determine the environment in which benthic community heterotrophic processes take place.

The oxidation of reduced molecules, e.g. organic compounds, by living organisms releases energy, part of which is stored via phosphorylation to adenosine triphosphate (ATP). For some (fermenting) organisms, oxidation of organic compounds is incomplete leading 
to simpler organic molecules: fermentation then allows only a relatively small part of the energy of the substrate to be used in ATP synthesis (substrate-level phosphorylation process). In most organisms, the oxidation of organic molecules is complete, however, leading to $\mathrm{CO}_{2}$ production, the electrons being transported along a respiratory chain to a terminal acceptor (Staley \& Orians 1992). This process allows a large part (up to $30 \%$ ) of the oxidation energy to be stored as ATP (oxidative phosphorylation process). The most usual terminal acceptor for electrons is oxygen which is reduced to $\mathrm{H}_{2} \mathrm{O}$ by aerobic respiration. In anoxic environments, anaerobic respiration takes place with other electron acceptors, e.g. metal hydroxides, nitrate or sulphate. The reduced end-products of these anaerobic processes then diffuse into the environment according to their concentration gradients and, in turn, may be used as electron donors (Bender \& Heggie 1984). Finally, except for volatile and/or solid species, these end-products are reoxidized by oxygen at the sediment-water interface, so that oxygen consumption reflects not only the aerobic, but also part of the anaerobic respiration (Jørgensen 1983). Therefore, metabolic (catabolic) activity is commonly estimated from measurements of oxygen consumption.

As most oxidation of organic material occurs in organisms having respiratory chains, an overall estimate of metabolism (aerobic plus anaerobic) can be obtained by measuring the activity through these chains. The method, known as Electron Transport System activity (ETSA) measurement, was described for marine applications by Packard $(1969,1971)$ and Packard et al. (1971). It consists of adding to homogenated samples a surplus of electron donors (NADH, NADPH, succinate) and of an artificial electron acceptor (INT: 2-p-iodophenyl-3-p-nitrophenyl-5-phenyl tetrazolium chloride). The reduction of the colorless INT to red formazan can be followed using a spectrophotometer at $490 \mathrm{~nm}$. The assay is based on the oxidation of the coenzyme $Q$-cytochrome D complex, which is rate-limiting. Therefore, assuming that enzymes are fully extracted in homogenates and are not inactivated, ETSA measurement gives an estimate of the metabolic potential of the organisms or communities sampled and exceeds, by far, the actual rate of electron transfer under natural conditions (Houri-Davignon et al. 1989).

The method has been improved with the introduction of the non-ionic detergent Triton X100 into plankton homogenated samples (Kenner \& Ahmed 1975 , Owens \& King 1975). Triton X100 solubilizes the formazan formed in the mixture assay and avoids the need for an organic extraction; it also strongly increases enzyme activity by improving the solubilization of membrane-bonded enzyme complexes. The method has been widely applied to plankton samples (see Packard 1985a, b) but less frequently to marine sediments (Wieser \& Zech 1976, Christensen \& Packard 1977, Olanczuk-Neyman \& Vosjan 1977, Pamatmat et al. 1981. Christensen 1983, Pfannkuche et al. 1983, de Wilde et al. 1986) and freshwater sediments (Zimmerman 1975, Jones \& Simon 1979, Broberg 1985). Various applications of the method can be found in Vosjan (1982).

The present paper is an attempt to report the stateof-the-art of ETSA measurement, with the goal of providing clearer ideas concerning the usefulness and the limits of this methodology as applied to sediments. After considering some technical problems, a new, accurate method is proposed. A review of data found in the literature (recalculated to use the same units) is presented to assess horizontal and vertical distribution of ETSA in marine sediments. Relationships to other biochemical and biological parameters, especially microbenthic biomass and respiration, are discussed in a companion paper (Relexans 1996 in this issue), with the goal of evaluating the meaning and usefulness of the method in present-day oceanographic studies and, finally, to decide whether it should be brought up to date or abandoned.

\section{METHODOLOGICAL PROBLEMS AND IMPROVEMENTS}

Basic procedures for ETSA measurements are given by Kenner \& Ahmed (1975) and Owens \& King (1975) for phytoplankton and for zooplankton, respectively. The steps involved in the assay are: (1) homogenization of the sample at a low $\left(0\right.$ to $\left.4{ }^{\circ} \mathrm{C}\right)$ temperature to obtain a cell-free extract in a buffered medium $\mathrm{pH} 8$ to 8.5) supplemented with the non-ionic detergent Triton $\mathrm{X} 100$; thus the cell-free extract contains the enzyme assemblages linked to suspended membrane fragments; and (2) incubation of the homogenate with an excess of electron donors (NADH, NADPH, succinate) and of an electron acceptor (INT), at a controlled temperature (generally near $20^{\circ} \mathrm{C}$ ) for 10 to $60 \mathrm{~min}$. By reading its absorbance over time with a spectrophotometer at $490 \mathrm{~nm}$, the reduction of INT to INTformazan versus time is measured and recorded. The results have to be corrected using turbidity blanks as well as 'chemical' blanks.

Comparison of methods was carried out by Christensen \& Packard (1979) on phytoplankton and bacteria. However, sediment samples gave rise to specific problems during the extraction step and in determining the blanks.

Homogenization of the sample. This step should allow complete recovery of the respiratory-enzyme 
units, without any destruction or inhibition of their activity. All methods involve refrigeration (generally in an ice bath, sometimes with $\mathrm{CO}_{2}$ : Olanczuk-Neyman \& Vosjan 1977) of the sample during homogenization. The methods used were (1) grinding the sample with sand in a mortar (Wieser \& Zech 1976); (2) the use of a mechanical homogenizer (OlanczukNeyman \& Vosjan 1977); and (3) homogenization of the sample with an ultrasonic apparatus (Christensen \& Packard 1977). Efficiencies of these different methods were checked by the authors, using various treatment strengths and durations. Olanczuk-Neyman \& Vosjan (1977), using a mechanical homogenizer, estimated that $95 \%$ of the total activity was recovered in the supernatant; in contrast, Jones \& Simon (1979) and Broberg (1985) found the use of a mechanical homogenizer to be of low efficiency compared with sonification. This poor efficiency of mechanical homogenizers seems to be supported by the fact that the results obtained by the method of Olanczuk-Neyman \& Vosjan (1977) are generally low compared with those obtained by other methods.

The problem of dilution of sediments in the homogenate is also critical. Authors have used from 0.6 (Wieser \& Zech 1976) to more than $100 \mathrm{ml}$ (Jones \& Simon 1979) of homogenization medium per gram of wet sediment. Wieser \& Zech (1976) found that 'success of extraction does not depend on the size of the sample'; their results were convincing with sediment samples but not with a species of ciliate, Geleia nigriceps, ground with quartz sand in a mortar: in the case of the ciliates, a relative decrease of dehydrogenase activity per hour and per individual was observed as the number of specimens was increased. Conversely, Jones \& Simon (1979) found the highest activities per $\mathrm{ml}$ of sediment when the sample was diluted with large volumes of buffer. Christensen (1981) discussed this point thoroughly and concluded that the non-linear relationship between absorbance and the dilution of the sediment sample could be due to residual, nonenzymatic color.

I personally tried to solve this problem, using the new procedure described below, allowing correction for chemical and reagent blanks, on various types of sediments. The ETSA per volume of wet sediment increased with the dilution of the sample in homogenization medium (vol/vol), up to dilutions of ca $1 / 20$ to 1/30 (Fig. 1)

However, the dilution of sediment samples can give rise to problems of detection limits and of reproducibility since the concentration of the formazan formed decreases with increasing sediment dilution in the assay. In other words, the loss in accuracy offsets the gain in extraction efficiency. Therefore, trials using various sample dilutions should be tested

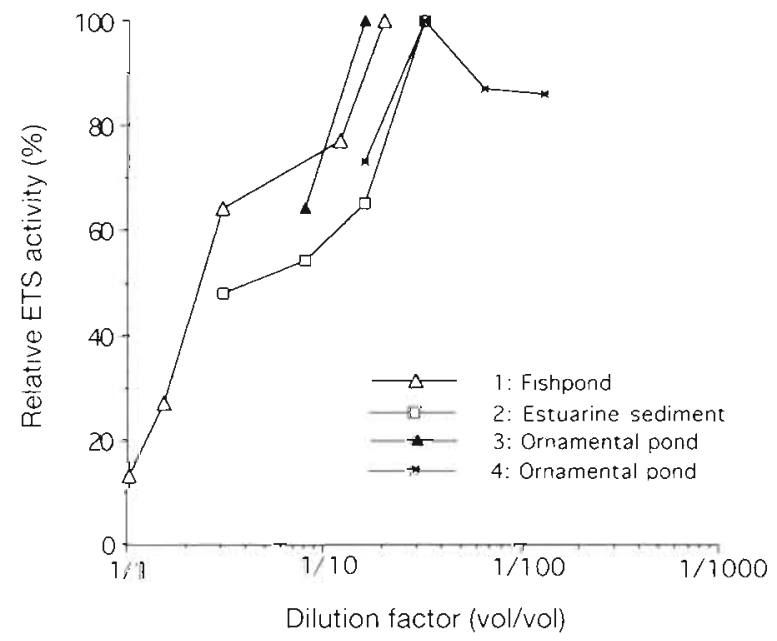

Fig. 1 Relative ETS activity (\% of maximum activity in each experiment) versus sediment dilution during the extraction step. (1) Manual grinding plus $4 \times 15 \mathrm{~s}$ ultrasonic treatment; (2 to 4) ultrasonic treatment applied to 4 successive extractions

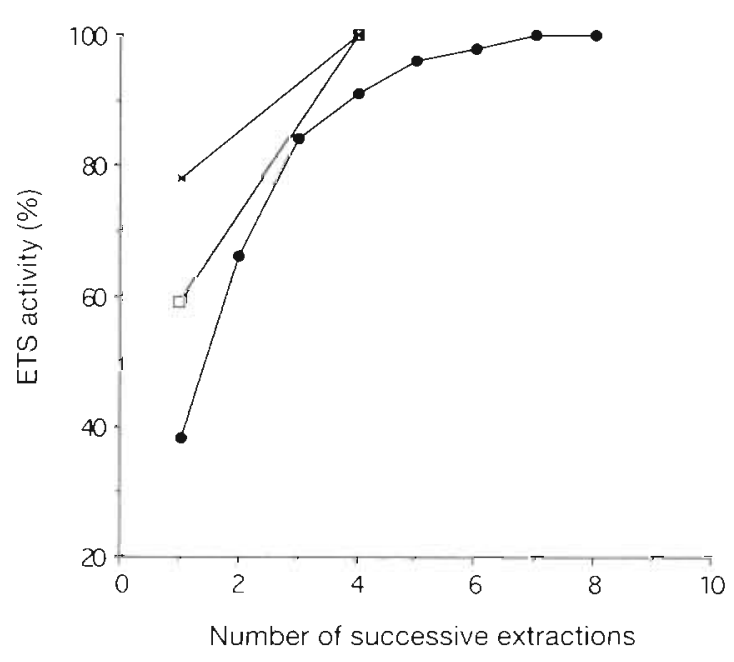

Fig. 2. Relative ETS activity (\% of maximum activity in each experiment) versus number of successive extractions. Onglnal results on 3 estuarine sediment samples

according to the types (with high or low activity) of sediments, to determine the best dilution to allow good recovery of activity without significant loss of accuracy.

Moreover, it has been found that for a given dilution (e.g. 1/16) and sonification protocol ( $3 \mathrm{~min}$; Christensen \& Packard 1977. Jones \& Simon 1979), a better recovery of ETS activity was obtained by 4 successive extractions, with $4 \mathrm{ml}$ of buffer for each of them, than a single extraction in $16 \mathrm{ml}$ (Houri-Davignon 1990; original data: Fig 2) A detailed description of the procedure is given below 


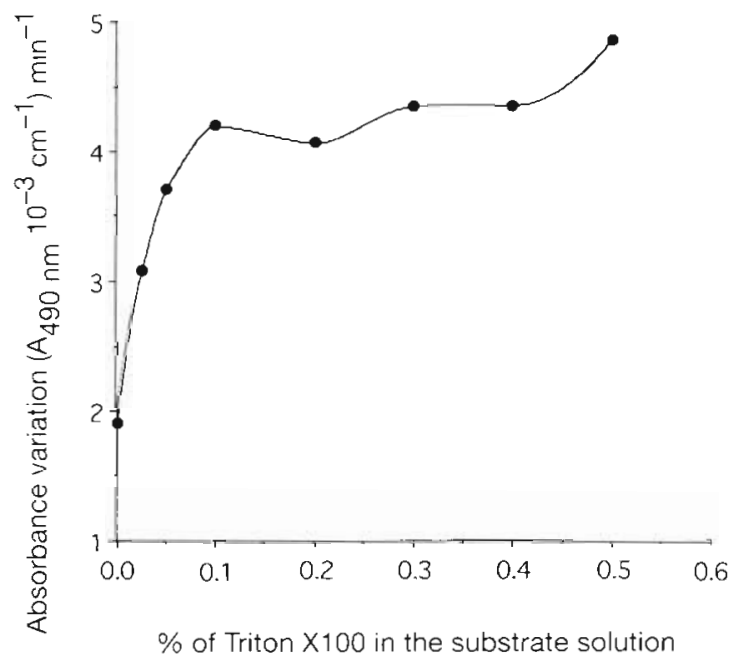

Fig 3. INT-reduction by NADH (reagent blank) versus concentration of Triton $X 100$ in the assay Concentration of $0.2 \%$ in the substrate solution $(0.16 \%$ final concentration) is routinely used

Correction with blanks. The colour contributed by the extract itself (turbidity blank; Kenner \& Ahmed 1975) must be taken into account when using endpoint methods; it remains constant for the duration of the assay.

Reduction of INT to formazan can occur in 2 ways: biological (enzymatic) and chemical. The chemical reduction has to be subtracted from total reduction to obtain the enzymatic production of formazan. The term 'chemical reduction' combines 2 reactions: (1) reduction of INT by the substrate (i.e. reagent blank); (2) reduction of INT by pre-existing reducing material in the sediment extract. Only this last reaction will be called 'chemical blank' in the following text.

The first reaction (reagent blank) depends both on the quality of the INT (e.g. supplier, storage conditions, age; Owens \& King 1975, Packard \& Williams 1981, Relexans \& Etcheber 1985) and on the Triton X100 concentration (Fig. 3). This control is easy to quantify by adding to the assay a series of tubes containing the substrate, INT lat the same concentration as in the standard assay) and homogenate buffer instead of sediment extract. With sediment samples of low activity, the reagent blank can be the main source of INT reduction and must be determined with high accuracy.

Reduction of INT by pre-existing reducing material is much more difficult to assess. Theoretically, the best way to discriminate the effects of enzymatic reactions from those which are non-enzymatic is to inhibit enzymes, for instance by adding formalin (Houri-Davignon 1990), heavy metals (Pamatmat \& Bhagwat 1973) or by boiling the homogenate (Packard 1969, Kenner \& Ahmed 1975, Wieser \& Zech 1976, Christensen 1981).
None of these methods is satisfactory here because either it destroys the reducing material the action of which it is expected to reveal (e.g. oxidation by heating), or it modifies the physico-chemical conditions of the assay (e.g precipitation of Triton X100 by heavy metals and/or by heating above $60^{\circ} \mathrm{C}_{i}$ modification of redox conditions by formalin). Some authors (HouriDavignon 1990) proposed that the homogenate should be kept at $4^{\circ} \mathrm{C}$ for 2 or $3 \mathrm{~d}$, corresponding to a period long enough to allow almost complete loss of enzyme activity. This last method is fairly satisfactory but requires repetition of the assay.

Therefore, a procedure introduced by Packard (1971), and followed later by numerous researchers, consists of adding to the standard assay a series of tubes containing only the homogenate plus INT, the substrate being replaced by the homogenization medium. In this procedure, it is assumed that the effect of the endogeneous substrate is negligible and that the INT reduction observed is mainly non-enzymatic (this should really be called the 'endogenic activity', i.e. resulting from joint chemical plus biological reduction of INT from all electron donors present). The chemical reduction of INT is generally low with well-oxygenated sediments but can be higher than the biological reduction, with samples of reduced coastal sediments.

Development of a new procedure for shipboard and laboratory measurements. The method presented here is an application of microtitration techniques, using microplates ( 96 wells of $400 \mu \mathrm{l}$ ) not treated for protein adsorption, and a special colorimeter equipped with a $492 \mathrm{~nm}$ filter. The method requires only very small amounts of homogenate and chemicals, and allows several replicates of the assay

Chemicals: The solutions used (Table 1; Brugeaille 1988) are derived from the procedure of Owens \& King (1975).

Homogenization: After gently mixing the sample with a spoon, exactly $1 \mathrm{ml}$ of wet sediment is removed (using a $1 \mathrm{ml}$ syringe with its tip cut off) and divided between two $5 \mathrm{ml}$ plastic test tubes each containing $2 \mathrm{ml}$ homogenate buffer. These test tubes are kept in ice. Four successive extractions are then made on these subsamples. Each of them is sonified (power: $100 \mathrm{~W}$ : frequency: $20 \mathrm{kHz}$ ) for $1 \mathrm{~min}$ (four $15 \mathrm{~s}$ bursts once every $30 \mathrm{~s}$; Christensen \& Packard 1977), and centrifuged at 4 to $8^{\circ} \mathrm{C}$ for $5 \mathrm{~min}$. Supernatants are carefully recovered and the pellets treated in the same way as the initial subsamples.

The procedure above is repeated 4 times, except that the sonification timing is varied, $1 \mathrm{~min}$ for the first extraction, $45 \mathrm{~s}$ for the next two and $30 \mathrm{~s}$ for the last. The supernatants are mixed together (total: $16 \mathrm{ml}$ for each $1 \mathrm{ml}$ sediment sample) and assayed for ETS activity. 
Table 1. Reagent preparation for present ETS method

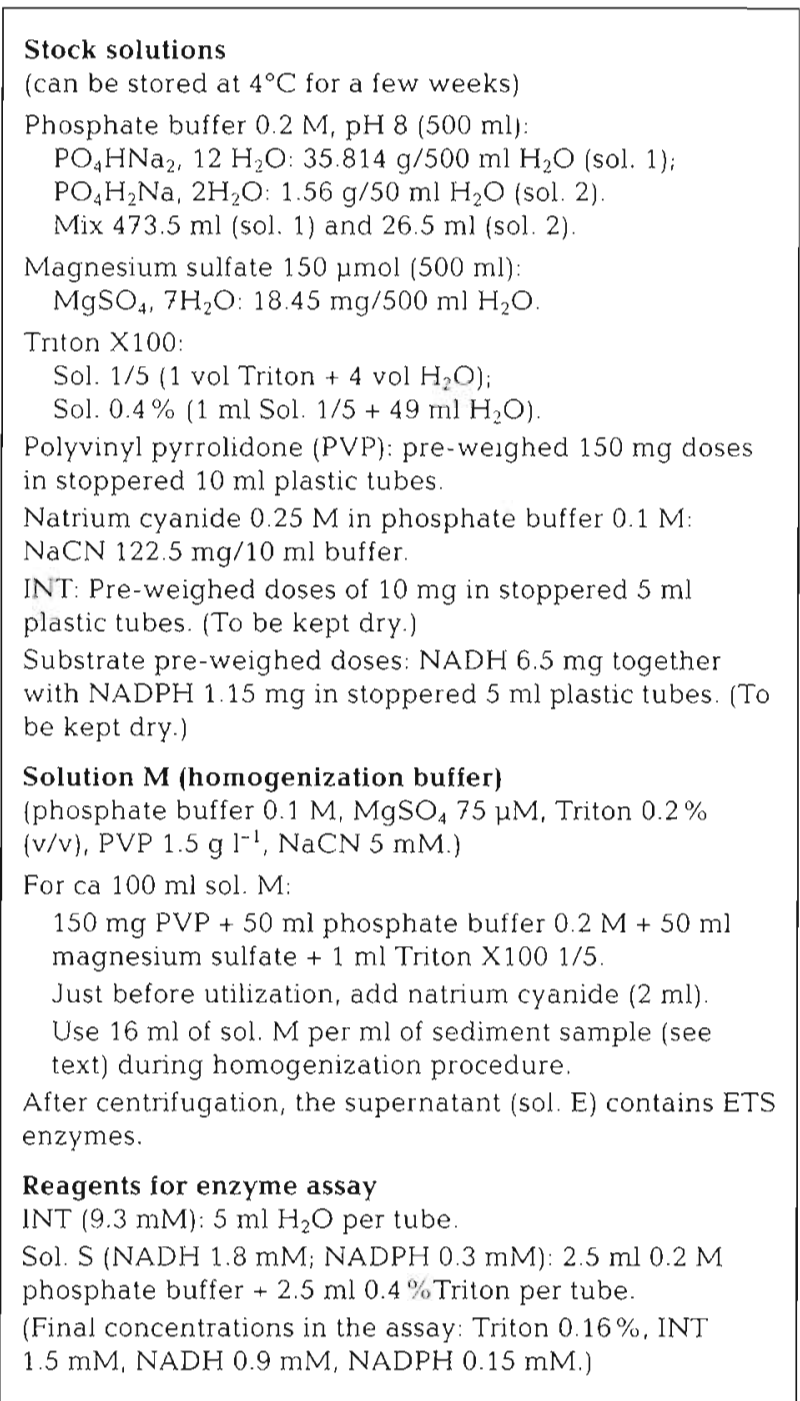

Assay: Substrates (S), INT and enzyme extracts (E) or extraction medium (M) are introduced into the wells of the microplates by means of a multiple distributor; the production of formazan versus time is followed by reading optical density (OD) each $5 \mathrm{~min}$, from 5 min (time required for temperature equilibration) to 20-30 min after introduction.

Typically, 3 series are made for each sample: (1) a 'reagent blank' series: 6 to 8 holes containing $\mathrm{S}$ $(150 \mu l)$, INT $(50 \mu l), M(100 \mu l)_{i}(2)$ a 'chemical' blank series: 6 to 8 holes containing $M(150 \mu l)$, INT $(50 \mu l)$, $E(100 \mu l) ;$ and (3) a 'reaction' series: 6 to 8 holes containing $\mathrm{S}(150 \mu \mathrm{l})$, INT $(50 \mu \mathrm{l}), \mathrm{E}(100 \mu \mathrm{l})$ (note that the amounts of $E$ can be reduced for samples with very high activity).

Time zero is taken as the time of introduction of $M$ (reagent blank) or E (reaction) and the time lag from one well to the other is taken into account when reading, so that all the wells are read at the same intervals.

Calculations: The mean curves of OD versus time are determined for the 3 series. The net slope of $\triangle O D$ (absorbance variation) versus time, due to enzymatic reduction of INT, is obtained by subtracting the sum of the slopes of series 1 and 2 from the slope of series 3 . After correction for optical path (each well should contain $380 \mu$ l to have $1 \mathrm{~cm}$ optical path), ETS is calculated as follows:

$$
\begin{aligned}
& \text { ETSA }\left(\mu l \mathrm{O}_{2} \mathrm{~h}^{-1} \mathrm{ml}^{-1} \text { of wet sediment }\right)= \\
& \Delta \mathrm{OD} \mathrm{h} \mathrm{h}^{-1} \times \mathrm{CV}(1 / 15900)(\mathrm{V} / \mathrm{e})(1 / \mathrm{s})(1 / 2) \times 24
\end{aligned}
$$

where $\triangle O D h^{-1}$ is net OD increase per hour, $c$ is correction for an optical path of $1 \mathrm{~cm}, v$ is volume of the assay $(0.3 \mathrm{ml}), 15900$ is the molar extinction coefficient of INT-formazan in $0.133 \%$ Triton X100 (Kenner \& Ahmed 1975), e is volume of homogenate in the assay $(0.1 \mathrm{ml}), V$ is total volume of the homogenate $(16 \mathrm{ml}), \mathrm{s}$ is volume of the sample $(1 \mathrm{ml}), 1 / 2$ is because $2 \mathrm{~mol}$ of formazan are equivalent to $1 \mathrm{~mol} \mathrm{O}_{2}$, and 24 is molar volume (l) at $20^{\circ} \mathrm{C}$.

As ETSA is a measurement for both aerobic and anaerobic organisms, some authors have expressed the results in electron equivalents (Christensen 1983, Packard et al. 1983). Since 4 electrons are required to reduce 1 molecule of oxygen, the value expressed in moles of $\mathrm{O}_{2}$ has to be multiplied by 4

Reproducibility: For the complete procedure (i.e. starting from the extraction step with a homogeneous sediment sample) applied to 4 replicates, the percentage standard deviation (coefficient of variation) was $2.83 \%$

\section{REVIEW OF LITERATURE DATA}

\section{Precautions for comparison of data}

Units

ETS activity (ETSA) has been most often reported in units of oxygen (mole or volume $\mathrm{h}^{-1}$ ) but Packard et al. (1983) pointed out that 'such units are meaningless when ETS is used as an index of nitrate reduction or denitrification'. Therefore, these authors proposed to report ETSA in electrochemical 'equivalents' which can be easily converted to moles $\mathrm{O}_{2}$, nitrate or nitrite, using the corresponding stoichiometric conversion factors (Packard et al. 1983).

In spite of the above considerations, I have chosen to express results found in the literature in the most commonly used units of $\mu \mathrm{O}_{2} \mathrm{~h}^{-1}$, keeping in mind that these units are conventional and do not necessarily involve a single aerobic pathway in benthic metabolism. 


\section{Sediment reference}

Results found in the literature have sometimes been reported per sediment surface, sometimes per sediment volume or wet/dry weight. I have expressed (where possible) all data in activity per $\mathrm{ml}$ and per gram of dry sediment. When information was not available for conversions, I estimated sediment densities and/or porosities from data previously obtained for sediments of similar characteristics.

\section{Temperature}

ETSA measurements may be given either at in situ temperature or at a constant temperature of the assay, for results taken as indices of in situ respiration or as biomass parameters, respectively. It is easy to convert ETSA at a given temperature to activity at another using Arrhenius' relationship:

$$
\mathrm{ETS}_{T_{1}}=\exp \left[\frac{E a}{R} \times\left(\frac{1}{T_{1}}-\frac{1}{T_{2}}\right)\right]
$$

where $T_{1}$ and $T_{2}$ are absolute temperatures, $R$ is the gas constant $\left(8.306 \mathrm{~kJ} \mathrm{~mol}^{-1}\right)$ and Ea is the apparent activation energy $\left(\mathrm{kJ} \mathrm{mol}^{-1}\right)$. I converted original data to ETS activities at $20^{\circ} \mathrm{C}$ using available values of $E_{a}$, or using a mean value of $41.8 \mathrm{~kJ} \mathrm{~mol}^{-1}$ (Brugeaille 1988, Houri-Davignon 1990) when Ea was not reported

\section{Geographic distribution of surface sediment ETS activity}

A compilation of data in various areas, from salt marshes to deep sea regions, is given in Table 2. ETSA values ranged from 0.6 to $475 \mu \mathrm{I} \mathrm{O}_{2} \mathrm{~h}^{-1} \mathrm{~g}^{-1}$ (mean: 186) in intertidal zones, 0.6 to $160 \mu \mathrm{O}_{2} \mathrm{~h}^{-1} \mathrm{~g}^{-1}$ (mean: 38) on the continental shelf, 0.5 to $10 \mu \mathrm{O}_{2} \mathrm{~h}^{-1} \mathrm{~g}^{-1}$ (mean: 4.6) on the slope, and 0.5 to $9 \mathrm{O}_{2} \mathrm{~h}^{-1} \mathrm{~g}^{-1}$ (mean: 4.6) in deep-sea areas. These results show a strong influence of depth on ETSA (Fig 4A).

Although the distribution of ETSA can mathematically be expressed as a logarithmic function of water depth, attention is drawn to (1) the very wide dispersion of values for similar ecological regions; (2) breaks in relationships at the shelf-slope discontinuity (200 to $300 \mathrm{~m}$ ); and (3) large discrepancies between ETSA levels in the different areas studied.

Largest variations have been noted in intertidal areas where various hydrodynamic conditions are encountered, strongly influencing distributions of both the sandy and the silty fractions, the organic carbon contents and the ETS activities. In contrast, in deep sea zones where conditions are more uniform, ETSA tends
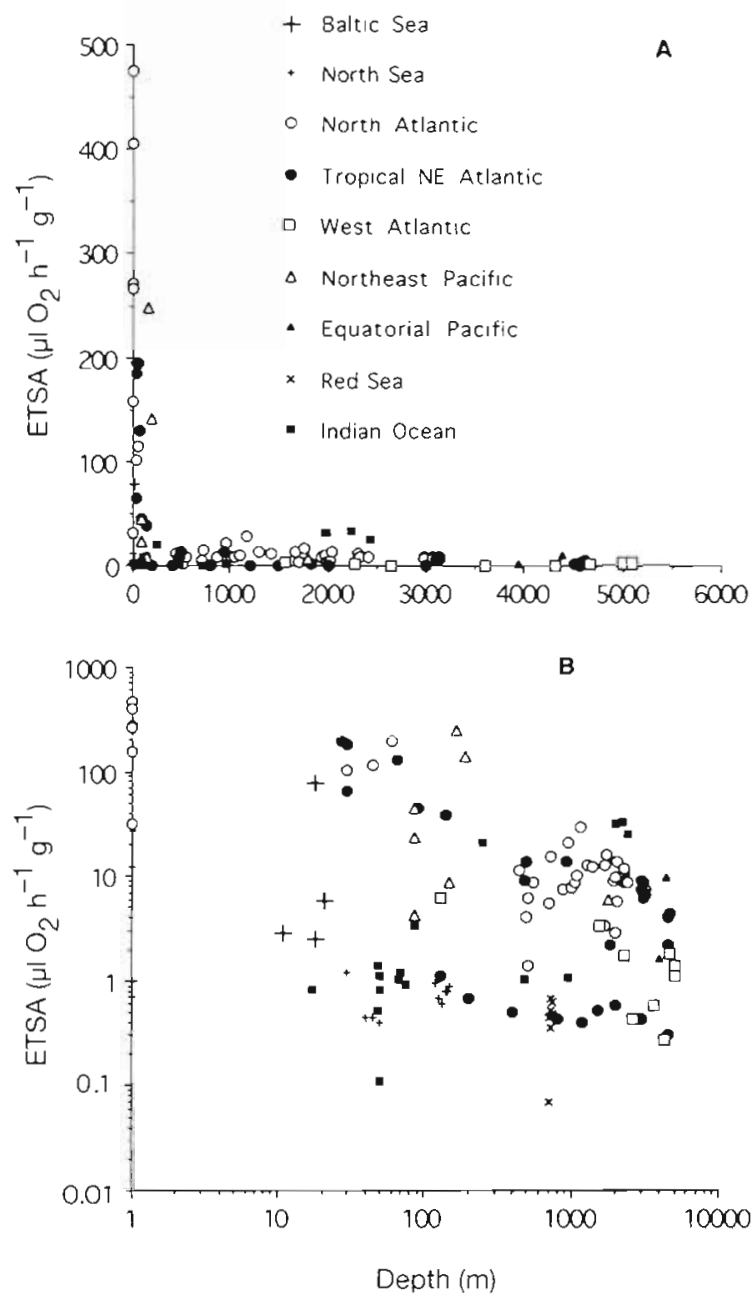

Fig. 4. (A) Variations of ETSA in surficial (0 to $1 \mathrm{~cm}$ ) sediment according to depth. (B) Same figure in log scale, for depth $>10 \mathrm{~m}$. ETSA is in $\mu l \mathrm{O}_{2} \mathrm{~h}^{-1} \mathrm{~g}^{-1}$ (dry weight) at $20^{\circ} \mathrm{C}$

toward similar, low values. Intermediate values have been found on the continental shelf

As ETSA is measured shipboard, attention must be paid to the effects of changes in environmental conditions (e.g. pressure and temperature) during recovery and incubation of the samples, especially for deep sea sediments. The effects of pressure on ETSA have been studied by King \& Packard (1975) with plankton homogenates. These effects were variable, according to species and temperature: for low temperature range 0.7 to $1.3^{\circ} \mathrm{C}$ ), application of 500 atm slightly decreased (less than $6 \%$ ) ETSA, compared with measures at 1 atm. The inhibition was higher (12 to $28 \%$ ) at higher temperature. Consequently, on average, shipboard ETSA measurements should be slightly overestimated even though, in most cases, a correction is not of major importance.

As for other enzymatic activities, temperature strongly affects ETS activity. The correction from the 


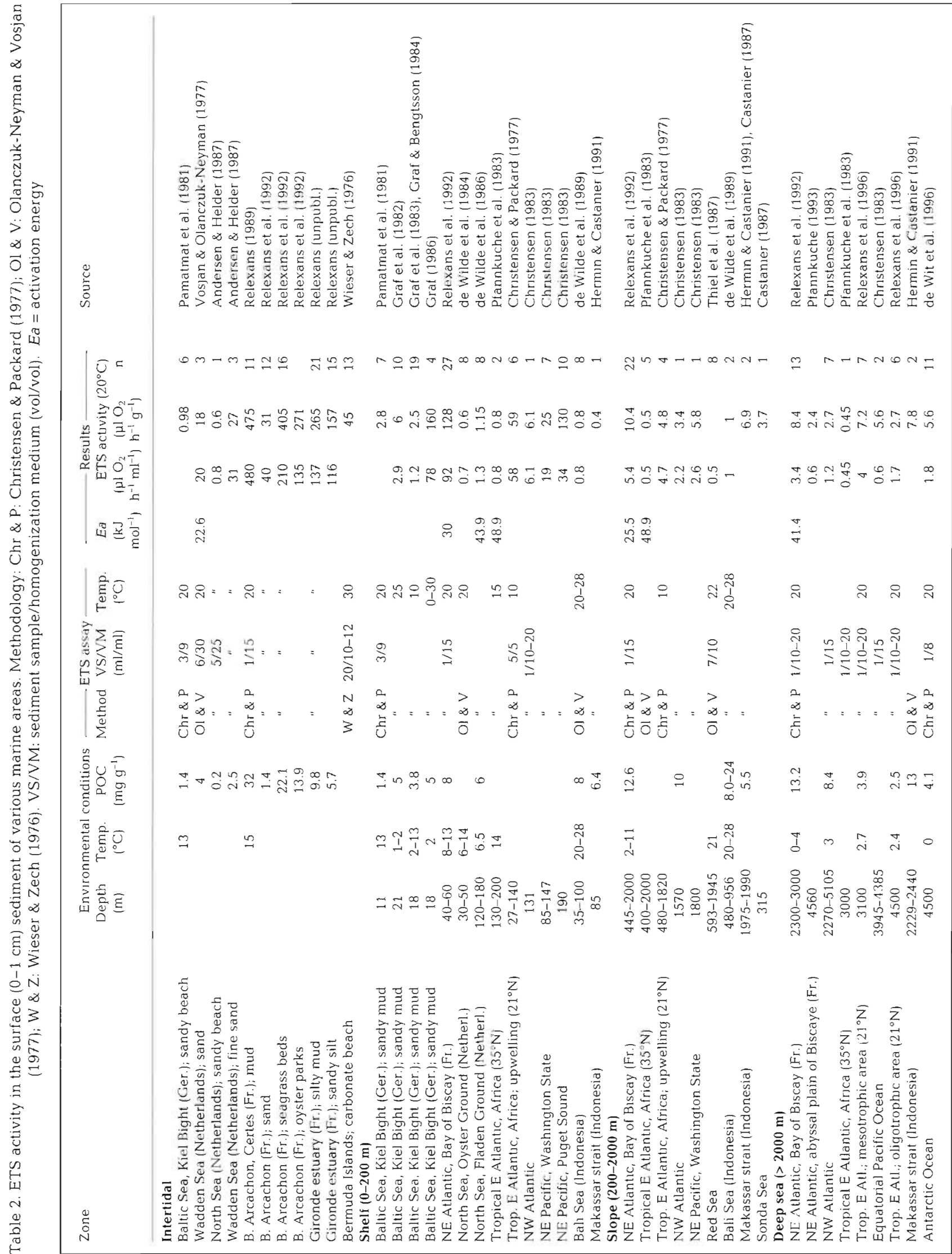


assay temperature to in situ temperature is easy, knowing the relevant activation energy Ea (see above). The problem of a possible loss of activity for deep sea organisms killed or inactivated when exposed to higher temperature than in situ, leading to underestimations of real ETSA, is more difficult to solve. Experiments in Bämstedt (1980), however, suggested that ETSA is probably rather well conserved during the time (a few hours) of retrieval and incubation of the samples. To what extent the opposite effects of increasing temperature and depressurization affecting deep sea samples may compensate one another is unknown but these uncertainties do not affect the pattern of variations of sediment ETSA versus depth.

The inverse relationship between ETSA and water depth (Fig. 4A) did not correspond to a simple exponential function. Generally a strong decrease in ETSA is found at the shelf break, while slightly increasing values are often apparent at about 1500 to $2000 \mathrm{~m}$. This increase is especially clear in the northeast Atlantic zone (Relexans et al. 1993a) and in the Makassar Strait (Indonesiai Hermin \& Castanier 1991). These results are consistent with the opinion of some authors who have attributed to the rise of the continental margin an important role in transport (and degradation) of particulate organic matter transiting from the continent to the deep acean (Jahnke et al. 1990, Monaco et al. 1990).

A log-log presentation of literature data (Fig. 4B) allows discrimination of zones of relatively low ETSA (Baltic Sea, North Sea, Red Sea) from zones, at similar depths, with relatively high activity (northeast and northwest Atlantic, northeast Pacific, Makassar Strait in Indonesia). Although methodological bias cannot be ruled out as a possible explanation for the differences observed, it is notable that the results are in good agreement with the overall organic carbon richness of the sediments in these regions.

\section{ETSA/particulate organic carbon ratios in surface sediments}

ETSA/particulate organic carbon (POC) ratios (Fig. 5) range from $155 \mu \mathrm{O} \mathrm{O}_{2} \mathrm{~h}^{-1} \mathrm{~g}^{-1}$ of POC (North Sea) to about 800 (Bay of Biscay, northeast Atlantic) for intertidal areas, and from $6 \mu \mathrm{O}_{2} \mathrm{~h}^{-1} \mathrm{~g}^{-1}$ (North Sea) to about 450 (northeast and tropical Atlantic) on the continental shelf. In deeper zones, ETSA/POC ratios tend to a uniform value of around $43 \mu \mathrm{O}_{2} \mathrm{~h}^{-1} \mathrm{~g}^{-1}[ \pm 6.5$, $95 \%$ CI (confidence interval), $n=63$ ] over all the regions examined. For the Atlantic Ocean, for which numerous data have been published (Elfaqir 1993, Relexans et al. 1993a) ETSA/POC ratios decrease drastically from the intertidal to the deep sea zone; more-

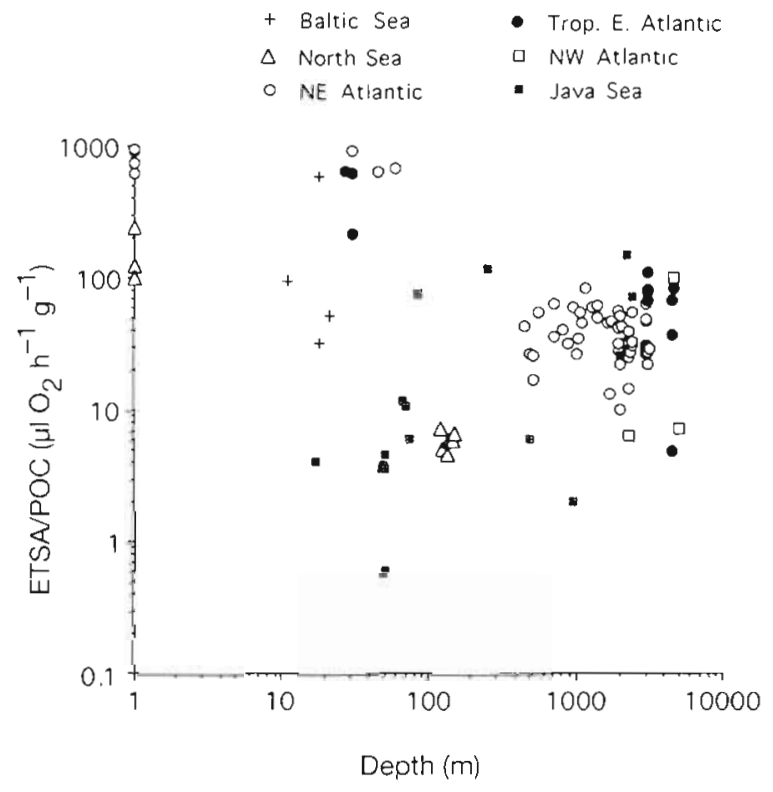

Fig. 5. ETSA/POC ratios $\left(\mu l \mathrm{O}_{2} \mathrm{~h}^{-1} \mathrm{~g}^{-1}\right.$ ) according to geographic zones and depths

over, as for ETSA (Fig. 4A), ETSA/POC values (Fig. 5) collapse at the shelf break while they increase slightly at the bottom of the slope, between 1000 and $1500 \mathrm{~m}$.

As ETS activity is linked to micro-meiobenthic organisms, variations of ETSA/POC ratios may reflect the quality of sedimenting of organic matter, with high ratios associated with a greater proportion of total carbon available for maintenance and/or growth of benthic biomass (Relexans et al. 1992, 1993a, b). In this scenario, the proportion of available (labile) organic matter reaching the sediment would be high (although variable) in coastal zones and decrease steeply with distance beyond the shelf break towards the deep ocean.

\section{Vertical distribution of ETS activity within sediments}

Numerous sediment ETSA versus depth profiles have been published for tidal areas (Wieser \& Zech 1976, Vosjan \& Olanczuk-Neyman 1977, Andersen \& Helder 1987), the continental shelf and the deep sea (Christensen \& Packard 1977, Christensen 1983, Pfannkuche et al. 1983, Thiel et al. 1987, Hermin \& Castanier 1991). A figure showing depth profiles of ETSA on an east-west transect at $21^{\circ} \mathrm{N}$ off the northwest African coast, by Christensen \& Packard (1977), illustrates well the various cases which may be encountered. Our original data from various areas of the northeast Atlantic Ocean are given in Fig. 6B.

In coastal zones, ETS activity is often maximal in the top few centimeters and decreases more or less 


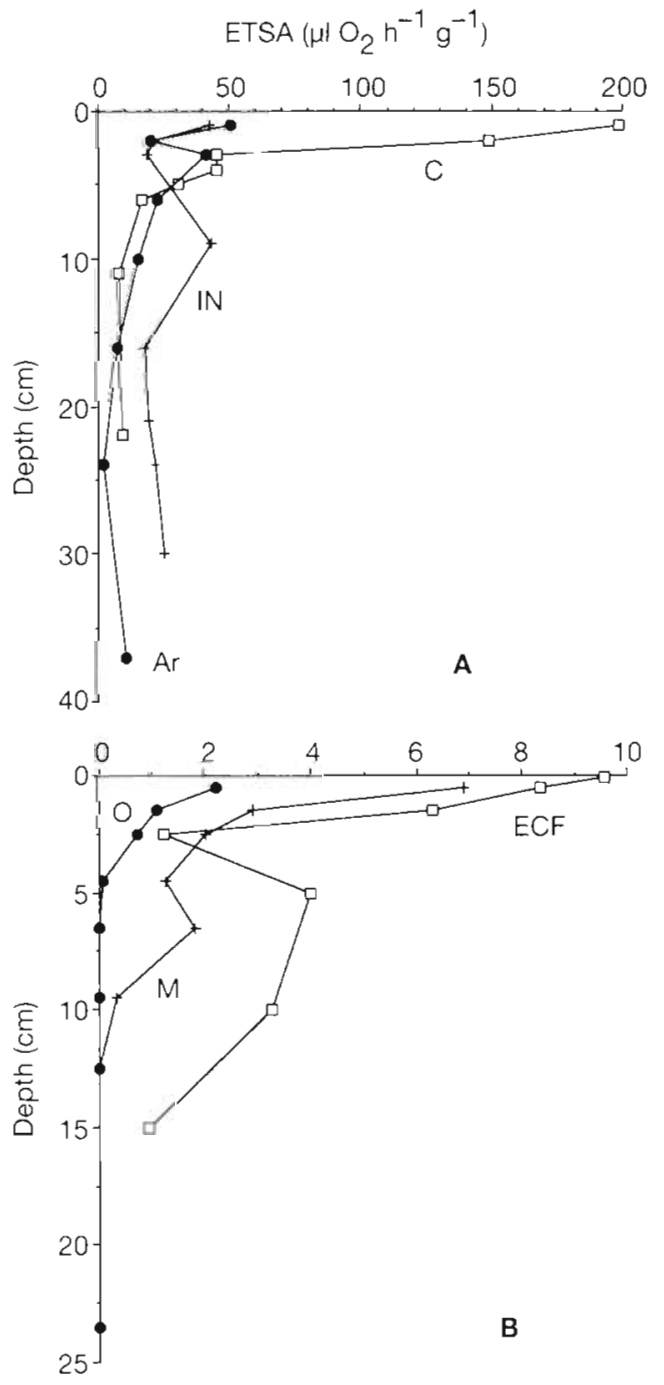

Fig. 6. Distribution of ETS activity within sediments; examples from the northeast Atlantic Ocean. (A) Three intertidal stations of the Bassin d'Arcachon, France; (B) ECF: ECOFER (Cap-Ferret Canyon; $2300 \mathrm{~m}$ ); $\mathrm{M}$ and $\mathrm{O}$ : EUMELI (tropical and northeast Atlantic; $M$ : mesotrophic, $3100 \mathrm{~m}$; O, oligotrophic, $4500 \mathrm{~m}$ )

regularly within the sediment (e.g. Fig. 6A). A variable, but measurable, ETSA has always been found in the deepest layers, even at more than $30 \mathrm{~cm}$ depth. On the contrary, within sediments of deep sea regions (Stns $\mathrm{O}$ and $\mathrm{M}$ in Fig. 6B), ETS activity drops below the detection limit. Zero (undetectable) activity tends to be relatively closer to the surface in the most oligotrophic zones.

Except for oligotrophic areas, the shapes of the profiles are mostly irregular: peaks of ETS activity are sometimes found in subsurface layers of coastal (Stns IN and Ar in Fig. 6A) and oceanic zones (ECOFER: Stn ECF in Fig. 6B); similar distributions were also noted by Christensen (1983), Pfannkuche et al. (1983) and Houri-Davignon (1990). In most cases, these peaks of ETS activity have been found below the limit of oxygen penetration and indicate the presence of anaerobic microorganisms.

Diurnal dependance of ETSA gradients was studied by Wieser \& Zech (1976) in a carbonate beach on Bermuda: samples taken in the morning, evening and the early part of the night showed more ETS activity in the top centimeter than did samples taken around noon. The authors interpreted these results to reflect vertical migration by some components of the sediment flora and fauna.

\section{CONCLUSION}

The application of ETSA measurements to sediments has been examined using original results and findings from the literature data. The main conclusions of the paper follow

(1) The lack of consistency of results among the different authors may likely be attributed to methodological bias, especially during recovery of the enzyme units. A new, accurate methodology using microplates is described for laboratory and shipboard purposes.

(2) The spatial distribution of ETS activity of surficial sediments follows a steep gradient from coastal zones to deep sea areas. An inflexion of the gradient is found at the top of the slope while a brief reversal occurs near the bottom of the slope which might play an important role for degradation of particulate material transiting along the oceanic margins.

(3) Within the sediment, ETS activity decreases to undetectable values at a few $\mathrm{cm}$ depth, in samples from oligotrophic areas. In rich coastal sediment, the gradient is irregular and ETS is still present in the deepest layers investigated, linked to anaerobic microbial populations.

Acknowledgements. I am grateful to Dr T. Soltwedel (University of Hamburg) for his constructive remarks and comments on the first version of the manuscript. A part of this work has been carried out within the ECOMARGE program supported by CNRS-INSU

\section{LITERATURE CITED}

Andersen FO, Helder W (1987) Comparison of oxygen microgradients, oxygen flux rates and electron transport system activity in coastal marine sediments. Mar Ecol Prog Ser 37. $259-264$

Bämstedt U (1980) ETS activity as an estimator of respiratory rate of zooplankton populations. The significance of variations in environmental factors. J Exp Mar Biol Ecol 42 267-283

Bender MIL. Heggie DT (1984) Fate of organic carbon reaching the deep sea floor: a status report. Geochim Cosmochim Acta 48:977-986 
Broberg A (1985) A modified method for studies of electron transport system activity in treshwater sediments. Hydrobiologra 120:181-187

Brugeaille M (1988) Qualification et quantification des biomasses dans la matière organique particulaire au sein de différents écosystèmes planctoniques et benthiques, par la mesure de l'activité des systèmes transporteurs d'électrons. Thèse de Doctorat, I Iniversité de Bordeaux

Castanier S (1987) Microbiogéologie: processus et modalités de la carbonatogenèse bactérienne. Thèse de Doctorat, Université de Nantes

Christensen JP (1981) Oxygen consumption, denitrification and sulfate reduction in coastal marine sediments. PhD dissertation, University of Washington, Seattle

Christensen JP (1983) Electron transport system activity and oxygen consumption in marine sediments. Deep Sea Res 30:183-194

Christensen JP, Packard TT (1977) Sediment metabolism from the northwest African upwelling system. Deep Sea Res 24: $331-343$

Christensen JP, Packard TT (1979) Respiratory electron transport activities in phytoplankton and bacteria: comparison of methods. Limnol Oceanogr 24:576-583

de Wilde PAWJ, Berghuis EM, Kok A (1984) Structure and energy demand of the benthic community of the Oyster Ground, Central North Sea. Neth J Sea Res 18(1-2): 143-159

de Wilde PAWJ, Berghuis EM, Kok A (1986) Blomass and activity of benthic fauna on the Fladen Ground (Northern North Sea). Neth J Sea Res 20(2-3):313-323

de Wilde PAWJ, Kastoro WW, Berghuis EM, Aswandy I, Al Hakim I, Kok A (1989) Structure and energy demand of the benthic soft-bottom communities of the Java Sea and around the Islands of Madura and Ball, Indonesia. Neth J Sea Res 23(4):449-461

de Wit R, Relexans JC, Bouvier T, Moriarty DJW (1996) Microbial respiration and diffusive oxygen uptake of deep-sea sediments in the Southern Ocean (ANTARES-I cruise). Deep Sea Res, part II (in press)

Elfaqir M (1993) Etude de la matière organique sur une marge continentale: quantité, qualité, bilan et réponses benthiques aux flux. Cas du Canyon du Cap-Ferret (Golfe de Gascogne). Thèse de Doctorat, Université de Bordeaux

Graf G (1986) Winter inversion of biomass and activity profile in a marine sediment. Mar Ecol Prog Ser 33:231-235

Graf G. Bengtsson W (1984) Heat production, activity of the electron-transport-system (ETS), the ratio heat/ETS-activity, and ATP-turnover as useful tools in benthic ecological field studies. Arch Hydrobiol Beih 19:249-256

Graf G, Bengtsson W, Diesner U, Schultz R, Theede H (1982) Benthic response to sedimentation of a spring phytoplankton bloom: process and budget. Mar Biol 67:201-208

Graf G, Schultz R, Peinert R, Meyer-Reil LA (1983) Benthic response to sedimentation events during autumn to spring at a shallow-water station in the western Kiel Bight. I. Analysis of processes on a community level. Mar Biol 77 . $235-246$

Hermin MN, Castanier S (1991) Evolution of organic matter diagenesis at water-sediment interface off-shore from the Mahakam delta, Indonesia. In: Bertheln J (ed) Diversity of environmental biochemistry; developments in geochemistry 6. Elsevier, Amsterdam, p 171-183

Houri-Davignon C (1990) Contribution à l'étude des relations entre les apports de matière organique particulaire à l'interface eau-sédiment et l'activité minéralisatrice du micro-méiobenthos. Thèse de Doctorat, Université dr: Bordeaux
Houra-Davignon C, Relexans JC, Etcheber H (1989) Measurement of actual electron transport system activity (ETS) in marine sediments by incubation with INT Environ Technol Lett 10:91-100

Jahnke RA, Reimers CE, Craven DB (1990) Intensification of recycling of organic matter at the sea floor near ocean margins. Nature 348(6296):50-54

Jones JG, Simon BM (1979) The measurement of electron transport system activity in freshwater benthic and planktonic samples. J Appl Bact 46:305-315

Jørgensen BB (1983) Processes at the sediment-water interface. In: Bolin B, Coox RB (eds) The major biochemical cycles and their interactions. Scope 21,J Wiley \& Sons, Chichester, p 477-509

Kenner RA, Ahmed SI (1975) Measurements of electron transport activities in marine phytoplankton. Mar Biol 33: $119-127$

King FD, Packard TT (1975) The effects of hydrostatic pressure on respiratory electron tranport system activity in marine zooplankton. Deep Sea Res 22:99-105

Monaco A, Biscaye $P$, Soyer J, Pocklington R, Heussner $S$ (1990) Particle fluxes and ecosystem response on a continental margin: the 1985-1988 Mediterranean ECOMARGE experiment. Cont Shelf Res 10:809-839

Olanczuk-Neyman KM, Vosjan JH (1.977) Measuring respiratory electron transport system activity in marine sediment. Neth J Sea Res 11:1-13

Owens TG, King $F$ (1975) The measurement of respiratory electron transport system activity in marine zooplankton. Mar Biol 30:27-36

Packard TT (1969) The estimation of oxygen utilization rate in seawater from the activity of the respiratory electron transport system in plankton. PhD thesis, University of Washington, Seattle

Packard TT (1971) The measurement of respiratory electron transport activity in marine phytoplankton. J Mar Res 29: $235-244$

Packard TT (1985a) Measurement of electron transport activity of microplankton. In: Jannasch $\mathrm{H}_{\text {, Williams PJleB (eds) }}$ Advances in aquatic microbiology, Vol 3. Academic Press, London, p 207-261

Packard TT (1985b) Oxygen consumption in the ocean: measuring and mapping with enzyme analysis. In: Zirino $A$ (ed) Advances in chemistry, Series 209, Mapping strategies in chemical oceanography. American Chemical Society, Washington, DC, p 177-209

Packard TT, Garfield PC, Martınez R (1983) Respiration and the respiratory enzyme activity in aerobic and anaerobic cultures of the marine denitrifying bacterium, Pseudomonas perfectomarinus. Deep Sea Res 30:227-243

Packard TT, Healy ML, Richards FA (1971) Vertical distribution of the activity of the respiratory electron transport system in marine plankton. Limnol Oceanogr 16:60-70

Packard TT, Williams PJleB (1981) Rates of respiratory oxygen consumption and electron transport in surface seawater from the northwest Atlantic. Oceanol Acta 4:351-358

Pamatmat MM, Bhagwat A (1973) Anaerobic metabolism in Lake Washington sediments. Limnol Oceanogr 18: $611-627$

Pamatmat MM, Graf G, Bengtsson W, Novak CS (1981) Heat production, ATP concentration and electron transport activity of marine sediments. Mar Ecol Prog Ser 4:135-143

Pfannkuche $O$ (1993) Benthic response to the sedimentation of particulate organic matter at the BIOTRANS station, $47^{\circ} \mathrm{N}, 20^{\circ} \mathrm{W}$. Deep Sea Res 40:135-149

Pfannkuche $O$, Theeg $R$, Thiel $H$ (1983) Benthos activity, abundance and biomass under an area of low upwelling 
off Morocco, Northwest Africa. 'Meteor' Forsch Ergebn $36: 85-96$

Relexans JC (1989) Effets des polluants sur la physiologie respiratoire de la méiofaune. Contrat no 87270, Ministère de l'Equipement et du Logement, de l'Aménagement du Territuire et des Transports-Environnement, Paris

Relexans JC (1996) Measurement of the respiratory electron transport system (ETS) activity in marine sediments: stateof-the-art and interpretation. II. Significance of ETS activity data. Mar Ecol Prog Ser 136:289-301

Relexans JC, Deming J, Dinet A, Gaillard JF, Sibuet M (1996) Sedimentary organic matter and micro-meiobenthos with relation to trophic conditions in the Northeast tropical Atlantic. Deep Sea Res (in press)

Relexans JC, Etcheber H (1985) La mesure de l'activité des systèmes transporteurs d'électrons (ETS): méthodologie; application au domaine estuarien. Océanis 11:443-459

Relexans JC, Etcheber H, Beliard M (1993a) Relationships between the quality of the organic matter and the benthic respiratory potential in surficial sediments of the Bay of Biscay (France). In: Sorbe JC, Jouanneau JM (eds) Third International Workshop on the Bay of Biscay. CNRS publisher, Arcachon, France, p 163-167

Relexans JC, Etcheber H, Castel J, Escaravage V, Auby I (1992) Benthic respiratory potential with relation to sedimentary carbon quality in seagrass beds and oyster parks

This article was submitted to the editor in the tidal flats of Arcachon Bay, France. Estuar Coast Shelf Sci 34:157-170

Relexans JC, Lin RG, Castel J, Etcheber H, Laborde P (1993b) Response of biota to sedimentary organic matter quality of the West Gironde mud patch, Bay of Biscay (France). Oceanol Acta 15(6):639-649

Smith KL Jr (1978) Benthic community respiration in the NW Atlantic Ocean: in situ measurements from 40 to $5200 \mathrm{~m}$. Mar Biol 47:337-347

Staley JT, Orians GH (1992) Evolution and the biosphere. ln: Butcher SS, Charlson RJ, Orians GH, Wolfe GV (eds) Global biochemical cycles. Academic Press, London, $\mathrm{p}$ $21-54$

Thiel H, Pfannkuche O, Theeg R, Schriever G (1987) Benthic metabolism and standing stock in the central and northern deep Red Sea. Mar Ecol 8(I):1-20

Vosjan JH (1982) Respiratory electron transport system activities in marine environments. Hydrobiol Bull 16(1):61-68

Vosjan JH, Olanczuk-Neyman KM (1977) Vertical distribution of mineralization processes in a tidal sediment. Neth J Sea Res 11(1):14-23

Wieser W, Zech $M$ (1976) Dehydrogenases as tools in the study of marine sediments. Mar Biol 36:113-122

Zimmerman AP (1975) Electron transport analysis as an indicator of biological oxidations in freshwater sediments. Verh Int Verein Theor Angew Limnol 19:1518-1523

Manuscript first received: July 3, 1995

Revised version accepted: December 18, 1995 